\title{
FACTORS OF PROJECT CONSULTANT SELECTION IN SAUDI
}

\section{ARABIA}

\author{
Abdeliazim Mustafa Mohamed ${ }^{1}$, Mohamed Abdelshafea Abdelraman ${ }^{2}$, Hishem Smaui ${ }^{3}$ \\ ${ }^{1,2}$ Civil Engineering Department, Alzaem Alazhari University (AAU), Sudan \\ ${ }^{1,3}$ Civil Engineering Department, Prince Sattam Bin Abdulaziz University (PSAU), Saudi Arabia \\ a.bilal@psau.edu.sa
}

\begin{abstract}
Project Consultants services in Saudi Arabia recently faced several problems such as conflicts between projects parties such as designer and project consultant. Inflexibility and Delay in reviewing, approving and work inspection by consultant, that are listed in [3] A total number of thirty four (34) questionnaire survey were collected from the government agencies and private companies in Kingdom of Saudi Arabia construction projects to evaluate the project consultant selection methods and their importance based to selected participant in the construction project, i.e., consultant, contractor, and the client. The field questionnaire survey conducted involved consultants, contractors, and clients. Numbers of five selection factors were determined during the research, calling for tenders, political influence, and pricing offer from the clients, ranking statues of the firms, experience and previous work of the firms. The data is analyzed using the SPS and average index [4]. The common factor of selection presented by all questioned parties is "Calling for tenders". Study concluded that number of $70 \%$ of Project Consultants were selected based on Calling for tenders.
\end{abstract}

Keywords: Construction, Project Consultant, Method of Selection, Saudi Arabia.

\section{INTRODUCTION}

The construction industry in Saudi Arabia recently grown fast, because of rapid construction expansion the quality and performance of consultant services need to be provided to meet the industry standard and client's satisfaction.

A construction project is one of major industry in Saudi Arabia like other countries significantly contributing in the growth of economic development. Achieving project completion at specified quality standards, within budget and on time is major factors success of project $[1,5,6]$. Although a lot of money has been spent in construction in Saudi Arabia, the construction industry is facing real challenges such as the cost overrun, delay of projects completion, building defects $[2,6]$.

This study intended to present the factors that affect selecting construction consultant services in the actual project and serve as a guide to the construction projects owner who would like to deal with Firms offering consultant services using questionnaire.

\section{RESEARCH METHOD}

Five (5) factors of consultant selection were identified through literature review and set of questionnaire distributed to the selected parties concerned in construction projects.

A set of combined description of questionnaire was developed to determine the occurrence of frequency, importance and severity of the particular factors. Contractor's records and information were collected from lists of contractors in the ministry of Commerce. Also, lists, record and information about consultants were collected from Engineering Consultation Directory part from Engineering Committee in Saudi Arabia [8].

Gathered questionnaire data distributed in construction field survey, analyzed by using statistical method to determine the frequency, important and important indices, considering the client as main part, contractor and consultant. Agreement between selected parties in the construction industry were also considered,

SPSS statistical package were used for data analysis included, one-way analysis of factor and variance analysis, using Average Index for the data collected for the critical factor analysis $[3,4]$.

\section{QUESTIONNAIRE DESIGN}

A set of questionnaire were separated into two sections. First section is general information about respondent and the company. Second section contains list of selected factors for project consultant in construction field. These factors are labeled into five (5) main factors. Questions were asked are categorized to five level scales as follows: substantially disagree, Disagree, Neutral, substantially agrees, and agree rarely on fifth to first scale. Consultants and contractors were required to answer questionnaire questions according to their experience and practical opinions in the construction field about the selection factors of project consultant. A set of 50 distributed questionnaires were returned 14 percent from public sector companies and 20 percent from the private sector. The total rate of return is $68 \%$. 


\section{RESULTS AND DISCUSSION}

\subsection{Calling for Tenders}

The selection base on Calling for tenders is one of the important factors taken into account by the client for the selection Project Consultant in Saudi Arabia construction industry. respondents agree that the client selection base on Calling for tenders in Saudi Arabia construction industry are shown in figure $4.1,48 \%$ is the highest ranking percent, for the respondent strongly agree $25 \%, 17 \%$ for the respondent who are neutral in their decisions, and $10 \%$ for the respondent who are agree with selection base on Calling for tenders, the average index which is 3.9.

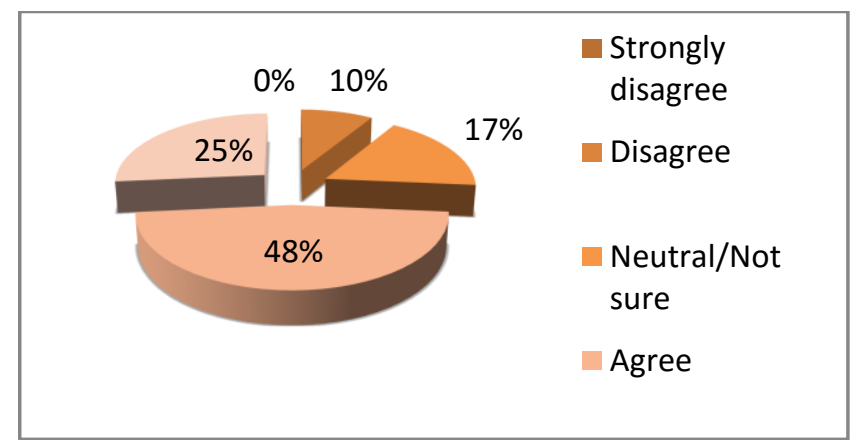

Figure 4.1: Selection factor based on calling for tenders

\subsection{Political Influence In Awarding Contracts}

The selection base on Political influence in awarding contracts is one of the important factors taken into account by the client for the selection Project Consultant in Saudi Arabia construction industry. respondents that are agree the client selection base on Political influence in awarding contracts in Saudi Arabia construction industry presented in figure 4.2, highest percent is ranking $46 \%$, for the respondent strongly agree $44 \%, 10 \%$ for the respondent who are neutral in their decisions, From the Table 4.6 average index score which is 4.35 .

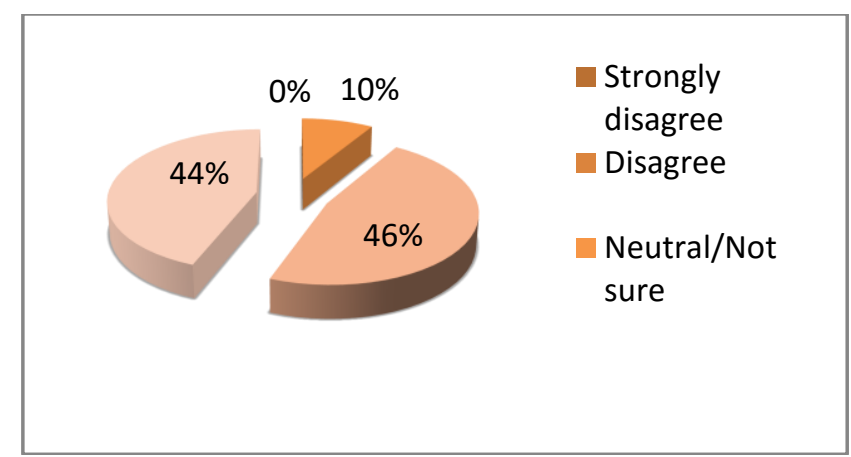

Figure 4.2: Selection factor based on political influence

\subsection{Selection Base On Pricing Offer From The Firms To The Clients}

The selection base on pricing offer from the firms to the clients is not one of the factors taken into account by the client for the selection Project Consultant in Saudi Arabia construction industry figure 4.3 it is notable that respondents
Disagree that the client selection base on Calling for tenders in Saudi Arabia construction industry, 41\% highest percent is ranking, $19 \%$ for the respondent strongly Disagree, for the respondent who are neutral in their decisions $27 \%$, and for the respondent who are agree with selection base on pricing offer from the firms to the clients is $13 \%$, the average index score 2.32 presented in Table 4.6

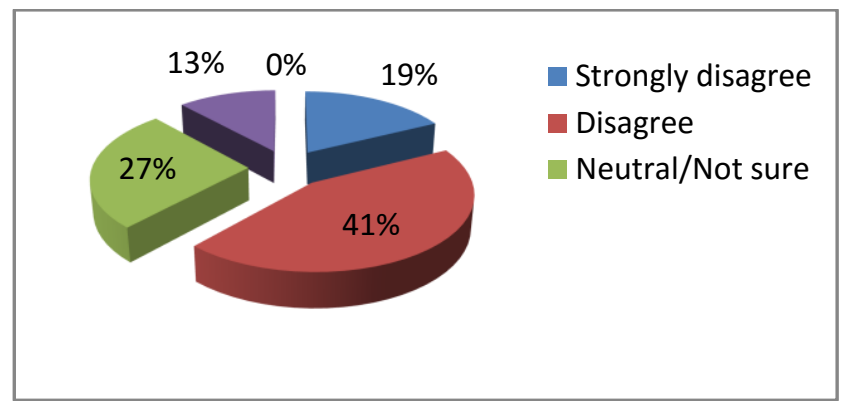

Figure 4.3: Selection factor based on pricing offer

\subsection{Selection Based On Ranking Statues of the Firms}

The selection base on ranking statues of the firms is not one of the factors taken into account by the client for the selection Project Consultant in Saudi Arabia construction industry. Respondents Disagree that the client selection base on ranking statues of the firms in Saudi Arabia construction industry presented figure $4.4 .47 \%$ it the highest percent in this factor, 33\% for the respondent strongly Disagree, the respondent who are neutral in their decisions is $9 \%$, and for the respondent who are agree with selection base on ranking statues $11 \%$. The average index score which is 2.01 are shown in table 4.6.

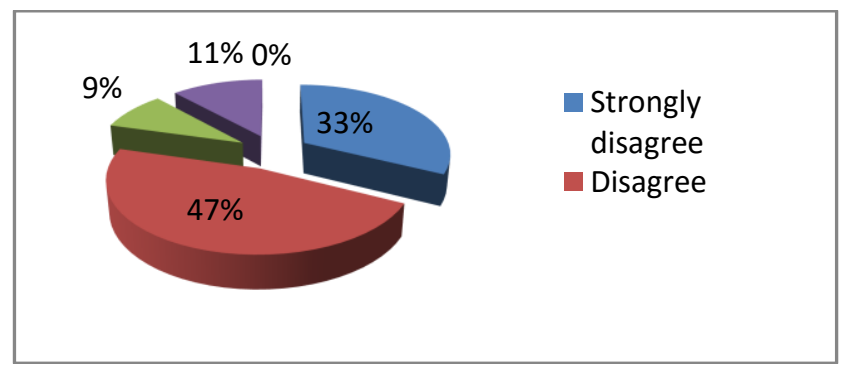

Figure 4.4: Selection factor based on ranking statues

\subsection{Selection base on previous work performed in past projects}

The selection base on previous work performed in past projects is one of the important factors taken into account by the client for the selection Project Consultant in Saudi Arabia construction industry. respondents strongly agree that the client selection base on previous work performed in past projects in Sudanese construction industry presented in figure $4.5,44 \%$ which is highest percent in this factor, $42 \%$ for the respondent who are agree, for the respondent who are neutral in their decisions is $14 \%$, average index score are reported in table 4.6 which is 4.29 . 


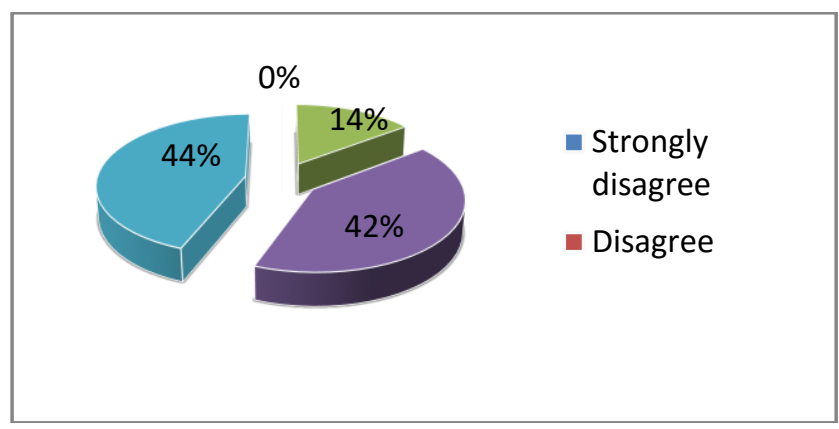

The overall results are tabulated in table 4.6 below. The survey summary on the selection factors of Project Consultant show that most of the factors listed were concerned by the respondents as selection factor for Project Consultant.

Figure 4.5: Selection factor based on previous work performed

Table 4.6: level of importance and Average Index

\begin{tabular}{|l|l|l|l|l|l|l|l|l|l|l|l|l|}
\hline No & Selection factor & $\mathbf{1}$ & $\mathbf{\%}$ & $\mathbf{2}$ & $\mathbf{\%}$ & $\mathbf{3}$ & $\boldsymbol{\%}$ & $\mathbf{4}$ & $\boldsymbol{\%}$ & $\mathbf{5}$ & $\boldsymbol{\%}$ & $\begin{array}{l}\text { Average } \\
\text { Index }\end{array}$ \\
\hline 1 & calling for tenders & 0 & 0 & 3 & 10 & 6 & 17 & 16 & 48 & 9 & 25 & 3.91 \\
\hline 2 & political influence & 0 & 0 & 0 & 0 & 3 & 10 & 16 & 46 & 15 & 44 & 4.35 \\
\hline 3 & pricing offer to the clients & 6 & 19 & 15 & 41 & 9 & 27 & 4 & 13 & 0 & 0 & 2.32 \\
\hline 4 & ranking statues & 11 & 33 & 16 & 47 & 3 & 9 & 4 & 11 & 0 & 0 & 2.01 \\
\hline 5 & previous work performed & 0 & 0 & 0 & 0 & 4 & 14 & 19 & 42 & 11 & 44 & 4.20 \\
\hline
\end{tabular}

"substantially disagree"

"Disagree"

"Neutral"

"Agree"

"substantially agree"
$5.00<$ Average Index $<4.50$

$3.50 \leq$ Average Index $<4.50$

$2.50 \leq$ Average Index $<3.50$

$1.50 \leq$ Average Index $<2.50$

$1.50 \leq$ Average Index $<1.00$

\section{CONCLUSION}

1. Calling for tender's and following to the average index the respondent that are "agree" this is one of the factors considered by the client for selecting Project Consultant in Saudi Arabia construction industry.

2. The average index for the Political influence in awarding contracts and the respondent that are "agree" this is one of the factors considered by the client for selecting Project Consultant in Saudi Arabia construction industry.

3. Based on the average index the respondent "Disagree" Selection base on pricing offer from the firms to the clients is one of the factors considered by the client for selecting Project Consultant in Saudi Arabia construction industry.

4. average index shows that the respondent that are "Disagree" the Selection Based on ranking statues of the firms is one of the factors considered by the client for selecting Project Consultant in Saudi Arabia construction industry.

5. The respondent "agree" the Selection base on previous work performed in past projects is one of the factors considered by the client for selecting Project Consultant in Saudi Arabia construction industry according to the average index.

\section{ACKNOWLEDGEMENT}

The authors would like to express their gratitude to $\mathrm{Mr}$. Abdelrhman Khalid Ali at the "Sudan Academy of Aviation Sciences and Technology", for his kind assistance.

\section{REFERENCES}

[1]. Chan DWM, Kumaraswamy M M. A Survey of timecost relationship in Hong Kong construction projects. Building Technology and Management Journal (Building Technology Society, School of Technology, Tunku Abdul Rahman College, Kuala Lumpur, Malaysia) 1993-1994;20: 54-72

[2]. Collier, K. (2005). Managing construction: the contractual viewpoint. 1st ed. Scarborough, ON: Nelson.

[3]. Harold, Kerzner (2004). "Advanced Project Management, Best Practices on Implementation." 2nd Edition, New Jersey, John Wiley \& Sons, Inc.

[4]. Mohamed A.M., (2011), project management consultant in Sudanese construction industry, Master Thesis, Universiti Teknologi Malaysia.

[5]. NEDO. Faster Building For Commerce HMSO, UK, 1988.

[6]. Rwelamila PD and Hall KA. Tool systems intervention: an integrated approach to time, cost and quality management. Construction Management and Economics 1995; 13: 235-241

[7]. Sadi A. Assaf *, Sadiq Al-Hejji. Causes of delay in large construction projects. International Journal of Project Management 24 (2006) 349-357

[8]. Smith Martin E. (2001). "What client employees say about consultants." Leadership \& Organization Development Journal, November 2001, pp. 93 - 103. 